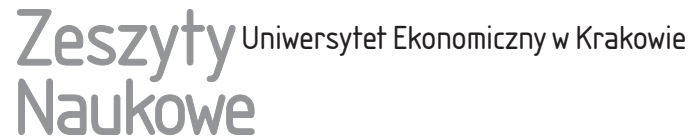

\section{Ewelina Kuberska}

\section{Koszt społeczny w rachunkowości}

\section{Streszczenie}

Cel: Celem artykułu jest zaproponowanie definicji pojęcia kosztu społecznego w rachunkowości w kontekście rozważań nad rolą i kierunkami rozwoju rachunkowości w dobie zrównoważonego rozwoju.

Metodyka badań: Do osiągnięcia celu wykorzystano metody jakościowe: metodę analizy literatury i metodę wnioskowania logicznego.

Wyniki badań: Rolą rachunkowości jest dostarczanie informacji o wpływie działalności przedsiębiorstw na społeczeństwo i środowisko. Na konieczność tę wskazują: nurt rachunkowości społecznej odpowiedzialności, teoria legitymizacji, koncepcja całkowitego rachunku kosztów oraz dyrektywa w sprawie ujawniania informacji niefinansowych.

Wnioski: Istniejąca w rachunkowości definicja kosztu wymaga rozszerzenia. Wyodrębnienie i określenie kategorii kosztu społecznego w rachunkowości daje możliwość prowadzenia kolejnych, niezwykle ważnych badań w tym zakresie, m.in. dotyczących pomiaru i wyceny kosztów społecznych, oraz jego uwzględniania w ramach wyniku finansowego przedsiębiorstwa.

Wkład w rozwój dyscypliny: Wyodrębnienie i uwzględnienie kosztu społecznego w rachunkowości przyczyni się do rozszerzenia zakresu badań w obszarze rachunkowości społecznej odpowiedzialności oraz uzupełni definicję kosztu przedsiębiorstwa w dobie zrównoważonego rozwoju.

Ewelina Kuberska, Uniwersytet Ekonomiczny w Poznaniu, Katedra Rachunkowości i Rewizji Finansowej, al. Niepodległości 10, 61-875 Poznań, e-mail: ewelina.kuberska@ue.poznan.pl, ORCID: https://orcid.org/0000-0003-4988-8613.

Artykuł udostępniany na licencji Creative Commons Uznanie autorstwa-Użycie niekomercyjne-Bez utworów zależnych 4.0 (CC BY-NC-ND 4.0); https://creativecommons.org/licenses/ by-nc-nd/4.0/ 
Słowa kluczowe: koszt społeczny, raportowanie niefinansowe, rachunkowość odpowiedzialności społecznej, dyrektywa w sprawie ujawniania informacji niefinansowych, informacje niefinansowe, koszty efektów zewnętrznych.

Klasyfikacja JEL: M40, M41, M49.

\section{Wprowadzenie}

Działalność człowieka pozostawia wyraźne ślady w postaci zmian ekologicznych. W ostatnim czasie rośnie zarówno liczba paneli dyskusyjnych i raportów dotyczących zmian klimatycznych, rozwiązań legislacyjnych wprowadzanych w tym obszarze, jak i świadomość ekologiczna społeczeństwa. Globalne problemy ekologiczne sprowadzić można do trzech podstawowych: nadmiernego zawłaszczania zasobów przyrodniczych oraz obciążenia środowiska, jakie stwarza wzrost gospodarczy i powiązana z nim konsumpcja, zmian klimatu oraz utraty bogactwa różnorodności biologicznej (Kassenberg 2011, s. 136). Wymuszają one na poszczególnych podmiotach gospodarczych zmianę podejścia do funkcjonowania. Dokonywanie zmian następuje w wyniku różnorodnych pobudek; mogą to być dobrowolne działania wynikające ze świadomego podejścia do środowiska, działania marketingowe i filantropijne, jak również obligatoryjne działania środowiskowe wynikające z przepisów prawnych. Pobudki te są mniej istotne, gdy rezultatem jest dobro naszego otoczenia. Dotychczas zainteresowanie interesariuszy działalnością przedsiębiorstwa odnosiło się do tego, co związane jest z jego wnętrzem. Należy przez to rozumieć wyniki, wskaźniki dotyczące wewnętrznych danych finansowych. Rachunkowość spełniała w tym obszarze kluczową rolę, pozostawiając jednak wiele kwestii do dalszych, głębszych badań i rozważań. Obecnie interesariusze są zainteresowani również tym, co jest związane z zewnętrznym otoczeniem jednostki - środowiskiem i społeczeństwem (wpływ na środowisko lokalne, relacje z pracownikami, wpływ na bioróżnorodność).

Sprawozdania finansowe stanowią istotne źródło informacji niezbędnych do oceny działalności podmiotu gospodarczego oraz determinujących decyzje użytkowników tychże sprawozdań. Wszelkie pozafinansowe informacje odnoszące się do działalności gospodarczej podmiotu prezentowane są w odrębnych raportach, co oznacza prezentację wycinkowego obrazu poszczególnych aspektów działalności. Próbę połączenia finansowych i pozafinansowych informacji o działalności podmiotu podjęto $\mathrm{w}$ ramach koncepcji sprawozdawczości określanej mianem sprawozdawczości zintegrowanej (Remlein 2015, s. 150).

Połączenie informacji finansowych z niefinansowymi i ich łączna prezentacja wymagają wypracowania rozwiązań w odniesieniu do kwestii zupełnie nowych i dotychczas nierozpatrywanych w rachunkowości. Rozważania należy rozpocząć 
od odpowiedzi na pytanie, w jaki sposób ująć, zmierzyć, wycenić i zaprezentować wpływ przedsiębiorstwa na społeczeństwo i środowisko.

Celem artykułu jest zaproponowanie definicji pojęcia kosztu społecznego w rachunkowości. Rozważania dotyczące kosztu społecznego w rachunkowości zostały poprzedzone omówieniem:

- roli rachunkowości w dobie zrównoważonego rozwoju,

- przesłanek przemawiających za koniecznością zdefiniowania kosztu społecznego w rachunkowości i prowadzenia badań w tym zakresie,

- pojęć i definicji stosowanych do określania kosztów społecznych przedsiębiorstw w rachunkowości.

Do osiągnięcia celu wykorzystano metody jakościowe: metodę analizy literatury i metodę wnioskowania logicznego.

\section{Rachunkowość w dobie zrównoważonego rozwoju}

W ostatnich latach zauważyć można większe zainteresowanie badaniami nad koncepcją zrównoważonego rozwoju. Zrównoważony rozwój powinien zapewnić obecnemu oraz przyszłym pokoleniom spełnienie wysokich standardów ekologicznych, ekonomicznych i społeczno-kulturowych w granicach pojemności ekosystemów, z zastosowaniem zasady sprawiedliwości wewnątrzpokoleniowej i międzypokoleniowej (Rogall 2010, s. 44). W czasach zwiększonego ryzyka związanego z katastrofami ekologicznymi i zmianami klimatu inwestorzy zaczęli przywiązywać większą wagę do upublicznianych przez przedsiębiorstwa informacji dotyczących zrównoważonego rozwoju, w tym ich wpływu na otoczenie. Badania nad rolą rachunkowości w dobie zrównoważonego rozwoju w skali międzynarodowej prowadzą m.in.: J. Bebbington, M.J Milne, R.H. Gray, B. O’Dwyer, D.L. Owen, I. Thompson, J. Unerman. B. Frame, J. Brown i C. Dey. W literaturze zidentyfikować można następujące obszary badań w tym zakresie:

- wyzwania stojące przed rachunkowością w dobie zrównoważonego rozwoju (Gray i Bebbington 2001, Milne i Gray 2007, Gabrusewicz 2011, Śnieżek i Perlińska 2012, Biadacz 2016, Bebbington, Russell i Thomson 2017),

- narzędzia służące do informowania o działaniach przedsiębiorstwa na rzecz zrównoważonego rozwoju (Paszkiewicz i Szadziewska 2011, Krasodomska 2018, Rubik 2018, Martyniuk i Romanchuk 2019),

- zakres i jakość informacji niefinansowych prezentowanych w raportach niefinansowych (Gray i in. 2001, Fijałkowska 2013, Krasodomska 2014a, Higgins, Stubbs i Milne 2018, Kawacki 2018, Adamczyk 2019, Bek-Gaik i Surowiec 2019, Skoczylas 2019, Stanek-Kowalczyk 2019), 
- rodzaj wytycznych stosowanych do tworzenia informacji niefinansowych (Rubik 2018, Ogrodnik 2019),

- jakość, wiarygodność i użyteczność informacji niefinansowych (Zyznarska-Dworczak 2015, Adamczyk 2019, Chojnacka i Jadanowska 2020, Papaj-Wlisłocka 2020),

- zaangażowanie przedsiębiorstw w publikowanie informacji niefinansowych (Lament 2017, Sikacz i Wołczek 2017, Aluchna, Kytsyuk i Roszkowska-Menkes 2018).

Informacje dostarczane przez rachunkowość przestają być wystarczające do podejmowania decyzji w warunkach zrównoważonego rozwoju. Istnieje potrzeba dysponowania informacjami odmiennymi, które dotychczas nie były prezentowane, a także ewidencjonowania i ujmowania ich w księgach rachunkowych. W związku z tym rola rachunkowości w dobie zrównoważonego rozwoju polega na dostarczeniu informacji użytecznych, wiarygodnych i porównywalnych, które wspomogą prowadzenie biznesu w sposób odpowiedzialny. Należy do nich informacja o koszcie społecznym przedsiębiorstwa.

\section{Przesłanki przemawiające za zdefiniowaniem kosztu społecznego w rachunkowości}

\subsection{Uwagi ogólne}

Terminologia wykorzystywana w rachunkowości jest bardzo obszerna. Część pojęć jest wielokrotnie definiowana, w zależności od potrzeb i prowadzanych badań. Zdarza się również, że stosuje się kilka różnych pojęć do opisu tego samego zjawiska. Nie ma możliwości prowadzenia badań bez wyodrębniania obiektu badań. Ten wymaga zaś określenia w postaci terminu, który wykorzystywany będzie do jego określania, oraz definicji, która wskazywała będzie na jego dokładny zakres. Złożoność otoczenia gospodarczego powoduje, że raz sformułowana definicja okazuje się niejednokrotnie niewystarczająca do prowadzenia badań. To, co obecnie dzieje się w rachunkowości, prowokuje do podjęcia dyskusji na temat konieczności wprowadzenia nowych terminów i ich definicji do nauki rachunkowości bądź zweryfikowania już istniejących. Konieczne wydaje się przyjęcie w nauce rachunkowości pojęcia kosztu społecznego, a przemawiają za tym m.in.:

- nurt rachunkowości odpowiedzialności społecznej,

- teoria legitymizacji w rachunkowości,

- koncepcja całkowitego rachunku kosztów,

- dyrektywa w sprawie ujawniania informacji niefinansowych. 
Przesłanki te wskazują na istotność kosztu społecznego i znaczenie jego wyodrębnienia dla rozwoju nauki rachunkowości.

\subsection{Nurt rachunkowości odpowiedzialności społecznej}

Pojęcie rachunkowości odpowiedzialności społecznej pojawiło się w literaturze m.in. w pracach T. Gabrusewicza (2010, s. 60), A. Kosiuka (2013, s. 116), D. Garsteckiego (2015, s. 52) i M. Macudy (2015, s. 1). Równorzędnie stosuje się takie pojęcia jak rachunkowość społeczna (Dyląg i Puchalska 2014, s. 25; Krasodomska 2014b, s. 192; Mikulska i Michalczuk 2014, s. 197; Garstecki 2015, s. 52; Biadacz 2017) czy rachunkowość społecznie odpowiedzialna (Garstecki 2015, s. 52; Biadacz 2017).

T. Gabrusewicz (2010, s. 60) definiuje rachunkowość odpowiedzialności społecznej jako rachunkowość uwzględniającą obciążenia i korzyści dla społeczeństwa wynikające z działalności konkretnego podmiotu gospodarującego, przedstawione w formie wartościowej lub opisowej. M. Macuda (2015, s. 1) wskazuje natomiast, że rachunkowość odpowiedzialności społecznej ma na celu identyfikację, pomiar i prezentowanie zagadnień społecznych i środowiskowych związanych z funkcjonowaniem przedsiębiorstwa. Autorka ta, włączając pomiar w zakres rachunkowości odpowiedzialności społecznej, dokonała zawężenia formy prezentowanych zdarzeń społecznych i środowiskowych. Zgodnie z definicją T. Gabrusewicza zdarzenia społeczne i środowiskowe mające charakter obciążeń lub korzyści dla społeczeństwa powinny być bowiem prezentowane w sposób opisowy bądź wartościowy.

Obecnie pewne informacje na temat wpływu działalności przedsiębiorstwa na otoczenie są już prezentowane przez niektóre przedsiębiorstwa w raportach pozafinansowych. Jedną z kategorii ujawnianych w raportach jest koszt społeczny, który prezentowany jest różnie, z wykorzystaniem niejednorodnych danych i mierników. Informacje na temat negatywnego wpływu przedsiębiorstw na otoczenie są istotne w dobie zrównoważonego rozwoju, dlatego szczegółowe rozpoznanie kosztu społecznego jako obiektu badań w rachunkowości jest kluczowe.

\subsection{Teoria legitymizacji w rachunkowości}

Przyczynę zainteresowania rachunkowości informacjami dotychczas nieprezentowanymi w sprawozdaniu finansowym trafnie opisuje teoria legitymizacji, stanowiąca kolejną przesłankę potwierdzającą konieczność zdefiniowania kosztu społecznego w rachunkowości. Teoria legitymizacji nie należy do nowych. Rozwijało ją wielu filozofów, m.in. J. Locke, T. Hobbes, I. Kant, Manegold von Lautenbach, a także ekonomistów. Do tych ostatnich należał M. Weber, uważany za twórcę teorii legitymizacji w światowej myśli ekonomicznej (Śnieżek 2016). O miejscu 
i zastosowaniu teorii legitymizacji w ramach badań naukowych w rachunkowości piszą: M.K. Power (2003), S. Ogden i J. Clarke (2005), J. Liu i D. Taylor (2008), W. Aerts i D. Cormier (2009), P. Archel i in. (2009), I.M. Beuren i M.L. Boff (2011), O. Georgiou i L. Jack (2011), a także M. Łada i A. Kozarkiewicz (2013), A. Jastrzębowski (2014), Ł. Matuszak (2015), M. Łada (2016), B. Zyznarska-Dworczak (2018). A. Szadziewska (2014a, s. 262) stwierdza, że zgodnie z teorią legitymizacji w obecnych warunkach utrzymanie się i rozwój podmiotów gospodarczych nie zależy tak jak dotychczas wyłącznie od osiągania wysokich wyników ekonomicznych, ale także od akceptacji ich działalności przez otoczenie. Wobec tego rachunkowość będzie wykorzystywana jako środek do uzyskania akceptacji, jej utrzymania bądź też odzyskania (Matuszak 2015, s. 114).

Dostarczanie informacji dotychczas niepublikowanych jest istotne nie tylko z punktu widzenia czynności sprawozdawczych przedsiębiorstwa. Poza ujawnianiem wpływu działalności przedsiębiorstw na otoczenie rozpatruje się także ujmowanie tego wpływu jako kategorii kosztu podczas ustalania wyniku w ramach całkowitego rachunku kosztów.

\subsection{Koncepcja całkowitego rachunku kosztów}

Koncepcja całkowitego rachunku kosztów ( full cost accounting) nie była dotąd omawiana w polskiej literaturze z zakresu rachunkowości. W literaturze anglojęzycznej określana jest zamiennie jako: environmental full-cost accounting, full environmental cost accounting, total cost accouting oraz total cost assessment (Jasinski, Meredith i Kirwan 2015, s. 1124). Celem całkowitego rachunku kosztów jest identyfikacja i wycena kosztów, zarówno tych występujących wewnątrz przedsiębiorstwa (direct cost), jak i tych zewnętrznych, generowanych przez przedsiębiorstwo oraz objawiających się w postaci występujących efektów zewnętrznych o charakterze społecznym i środowiskowym (environmental and social externalities), lecz ponoszonych przez jednostki trzecie (indirect cost) (Bebbington i Gray 2001, s. 24; D’Onza, Greco i Allergini 2016, s. 60). Koncepcja ta potwierdza konieczność zaproponowania definicji kosztu społecznego, który jest ściśle z nią związany. Teorie i koncepcje związane z rachunkowością społecznej odpowiedzialności i sprawozdawczością społeczną znalazły swoje praktyczne odzwierciedlenie w dyrektywie w sprawie ujawniania informacji niefinansowych.

\subsection{Dyrektywa w sprawie ujawniania informacji niefinansowych}

Za najważniejszą unijną inicjatywę ustawodawczą w zakresie ujawniania informacji środowiskowych, społecznych i związanych z ładem korporacyjnym uznaje się Dyrektywę Parlamentu Europejskiego 2014/95/UE z dnia 22 października 2014 r. zmieniającą dyrektywę 2013/34/UE w odniesieniu do ujawniania 
informacji niefinansowych i informacji dotyczących różnorodności przez niektóre duże jednostki oraz grupy. Dyrektywa nakłada na duże europejskie jednostki obowiązek ujawniania informacji dotyczących kwestii środowiskowych, społecznych, pracowniczych, poszanowania praw człowieka, a także przeciwdziałania korupcji oraz łapownictwu. Jednostki te muszą ponadto ujawnić politykę różnorodności stosowaną wobec swoich organów administrujących, zarządzających i nadzorczych. Przepisy dyrektywy zostały wdrożone przez wszystkie kraje członkowskie, w tym Polskę, i obowiązują od 1 stycznia 2017 r. (Remlein 2019, s. 49). Minęły cztery lata, odkąd określone przedsiębiorstwa raportują informacje niefinansowe. Część z nich publikuje jednak mniej lub bardziej dokładne informacje niefinansowe już od dłuższego czasu.

Rozważania naukowe powinny dążyć do stworzenia teorii, która lepiej wyjaśni i zobrazuje otaczający nas świat i jego problemy. Niepodważalnie praktyka gospodarcza i jej otoczenie potrzebują jak najlepszych narzędzi do komunikowania się z interesariuszami. Dlatego nauka rachunkowości musi się rozwijać, tworząc nowe teorie, pojęcia, metody i koncepcje. Jednym z nowych i koniecznych pojęć w nauce rachunkowości jest koszt społeczny. Jego wprowadzenie spowoduje powstanie kolejnych naukowych problemów do rozwiązania, a wśród nich będą m.in. kwestie jego pomiaru i wyceny.

\section{Istota kosztu społecznego w rachunkowości}

W polskiej literaturze z zakresu rachunkowości występuje wiele pojęć kosztów, które wskazują na powiązanie ze sferą społeczną i środowiskową. Do tych pojęć zaliczyć należy m.in.: koszty społeczne, koszty działań społecznych, koszty związane z działalnością społecznie niepożądaną, koszty zewnętrzne (koszty efektów zewnętrznych), koszty środowiskowe, czy też koszty ochrony środowiska.

Pojęcie kosztów społecznych nie jest często stosowane w literaturze przedmiotu. Ponadto nie jest w literaturze nauki rachunkowości definiowane i nie stanowi przedmiotu rozważań autorów. Pojawia się jako element służący do opisu bardziej złożonych problemów. Przykładowo B. Zyznarska-Dworczak (2014, s. 148) pojęcie kosztów społecznych stosuje w następującym kontekście: ,(...) tradycyjne rachunki nie pozwalają na generowanie pełnej informacji o kosztach społecznych, a tym samym przeprowadzanie rachunku ekonomicznego opartego na ich informacjach jest niekompletne i nie pozwala realizować założeń koncepcji odpowiedzialności społecznej”. W artykule M. Matuszak (2015, s. 118) czytamy natomiast: „,...) przedsiębiorstwo wykorzystuje zasoby danego społeczeństwa, w zamian za co dostarcza produkty i usługi, ale także zanieczyszcza środowisko (koszty społeczne)". 
Kolejną kategorią kosztów związanych ze sferą społeczną są koszty działań społecznych. Podobnie jak koszty społeczne nie stanowią oddzielnie rozpatrywanej kategorii. A. Nowak (2014, s. 234) stwierdza: „(...) w działaniach związanych ze społeczną odpowiedzialnością problemem nie jest oszacowanie kosztów, lecz oszacowanie przychodów". Na kategorię kosztów działań społecznych wskazuje także A. Szadziewska (2014b, s. 98): „(...) przedsiębiorstwa wykorzystują różne podejścia do rozliczania za sprawy społeczne, a mianowicie (...) przygotowywanie szacunku kosztów działań społecznych”. Autorka zwraca również uwagę na koszty związane z działalnością społecznie niepożądaną, tj. np. powodującą skutki szkodliwe dla środowiska przyrodniczego.

Istotną kategorię kosztów stanowią koszty środowiskowe. Pojęcie to jest dość często definiowane i najbardziej ugruntowane spośród wymienionych. Koszt środowiskowy to suma kosztu ponoszonego przez przedsiębiorstwo, który jest policzalny i ma wpływ na wynik finansowy przedsiębiorstwa (internal cost), oraz kosztu efektów zewnętrznych (external cost) wynikającego z wpływu prowadzonej przez przedsiębiorstwo działalności na społeczeństwo i środowisko, który dotychczas nie stanowi elementu uwzględnianego w określaniu wartości wyniku finansowego (Dascalu i in. 2010, s. 7).

Węższe spojrzenie na koszty środowiskowe przedstawia B. Piontek, definiując koszty środowiskowe jako straty środowiskowe i nakłady środowiskowe. Wskazuje on, że straty środowiskowe są szerokim zagadnieniem i zjawiskiem zarówno globalnym, jak i odnoszącym się do podmiotów gospodarujących. Najogólniej w ujęciu przedmiotowym - należy je rozumieć jako (Piontek 1999, s. 159):

- uszczuplenie majątku narodowego w wyniku uszkodzenia lub zniszczenia różnego rodzaju dóbr ekonomicznych i społecznych. Zaliczyć tu należy: straty z tytułu korozji, dewastacji budynków i urządzeń, niszczenie lasów i biocenozy wód;

- utratę określonych możliwości wytwórczych, spowodowaną zanieczyszczeniem lub przekształceniem różnych elementów środowiska. Są to: straty w postaci zmniejszenia plonów w rolnictwie zarówno na skutek zanieczyszczenia powietrza i gleby, jak i na skutek przekazywania ziemi na inne cele, zmniejszenie możliwości wykorzystania zasobów naturalnych, utrata surowców odprowadzanych jako odpady;

- zniszczenie krajobrazu;

- pogorszenie warunków zdrowotnych i jakości życia człowieka.

Przez nakłady środowiskowe B. Piontek rozumie natomiast celowe zużycie środków rzeczowych (wyrażone w cenach) i pracy żywej (wyrażone w płacach) związane z działalnością ekologiczną, a więc ochroną, kształtowaniem i restytucją środowiska (Piontek 1999, s. 160). Pojęcie nakładów środowiskowych zbliża nas do pojęcia kosztów ochrony środowiska. Koszty te to wyrażone w pieniądzu 
zużycie zasobów w celu osiągnięcia bieżących lub przyszłych korzyści związanych z ochroną środowiska, która pozwoli używać zasobów środowiska dziś i w przyszłości, zapewniając w ten sposób możliwość prowadzenia działalności gospodarczej bez ograniczenia czasowego (Famielec i Brodniewicz 2006, s. 23).

Rozszerzony i uporządkowany sposób prezentacji kosztów środowiskowych przedstawia A. Szadziewska. Autorka, powołując się na C. Jasch (2003, s. 669), stwierdza, że koszty środowiskowe to koszty zewnętrzne oraz wewnętrzne, które powstają zarówno w związku z niszczeniem, jak i ochroną środowiska przyrodniczego. Dzielą się one na (Szadziewska 2012, s. 47-48):

1) koszty wewnętrzne, do których zalicza się:

- koszty bieżące ochrony środowiska ponoszone na zapobieganie powstawaniu zagrożeń, zabezpieczenie przed ich wpływem, ograniczanie lub eliminowanie zanieczyszczeń, naprawę zaistniałych zniszczeń wynikających z bieżącej działalności firmy,

- nakłady inwestycyjne na przedsięwzięcia z zakresu ochrony środowiska;

2) koszty zewnętrzne, do których zalicza się:

- koszty wynikające z efektów zewnętrznych, podlegające internalizacji przez odpowiednie instrumenty stosowane w polityce ekologicznej państwa (koszty bieżące ochrony środowiska wynikające $\mathrm{z}$ obowiązujących przepisów, tj. kontrola emisji, podatki i opłaty ekologiczne),

- koszty wynikające z efektów zewnętrznych niepodlegające internalizacji (koszty związane $\mathrm{z}$ funkcjonowaniem jednostki w danym środowisku, powodującym jego zanieczyszczenie, obciążające społeczeństwo, środowisko, inne podmioty).

Powiązania pomiędzy wyodrębnionymi wyżej pojęciami obrazuje rys. 1 .

Koszty społeczne to kategoria kosztów środowiskowych przedsiębiorstwa. Nie są one obecnie uwzględniane w wyniku finansowym. Można przypuszczać, że internalizacja kosztów efektów zewnętrznych przyczynia się do uwzględnienia części kosztów społecznych w kosztach ochrony środowiska, czyniąc je kosztami wpływającymi na wynik finansowy. Kluczowe wydaje się w tym momencie wskazanie kilku elementów podważających tę opinię, a mianowicie:

- internalizacja kosztów efektów zewnętrznych nie oznacza, że straty środowiskowe odczuwane przez społeczeństwo nie występują,

- internalizacja kosztów efektów zewnętrznych niejednokrotnie wskazuje na płatność za użytkowanie środowiska, nie eliminuje to jednak kosztów społecznych ponoszonych przez społeczeństwo,

- wykorzystanie podatków i opłat środowiskowych przez instytucje rządowe na działania prośrodowiskowe nie eliminuje występowania luki kosztów społecznych, czyli okresu trwającego od czasu, kiedy koszt społeczny zaczął być ponoszony 
przez społeczeństwo, do czasu zminimalizowania kosztów społecznych przez działania rządowe,

- koszty społeczne wyrażone w wartości opłat środowiskowych i podatków mogą nie odzwierciedlać wielkości kosztu społecznego ponoszonego przez społeczeństwo.

Powyższe argumenty modą dowodzić, że traktowanie kosztów zewnętrznych (internalizowanych) jako kosztów społecznych, które są uwzględniane w wyniku finansowym przedsiębiorstwa, jest niewystarczające w dobie zrównoważonego rozwoju.

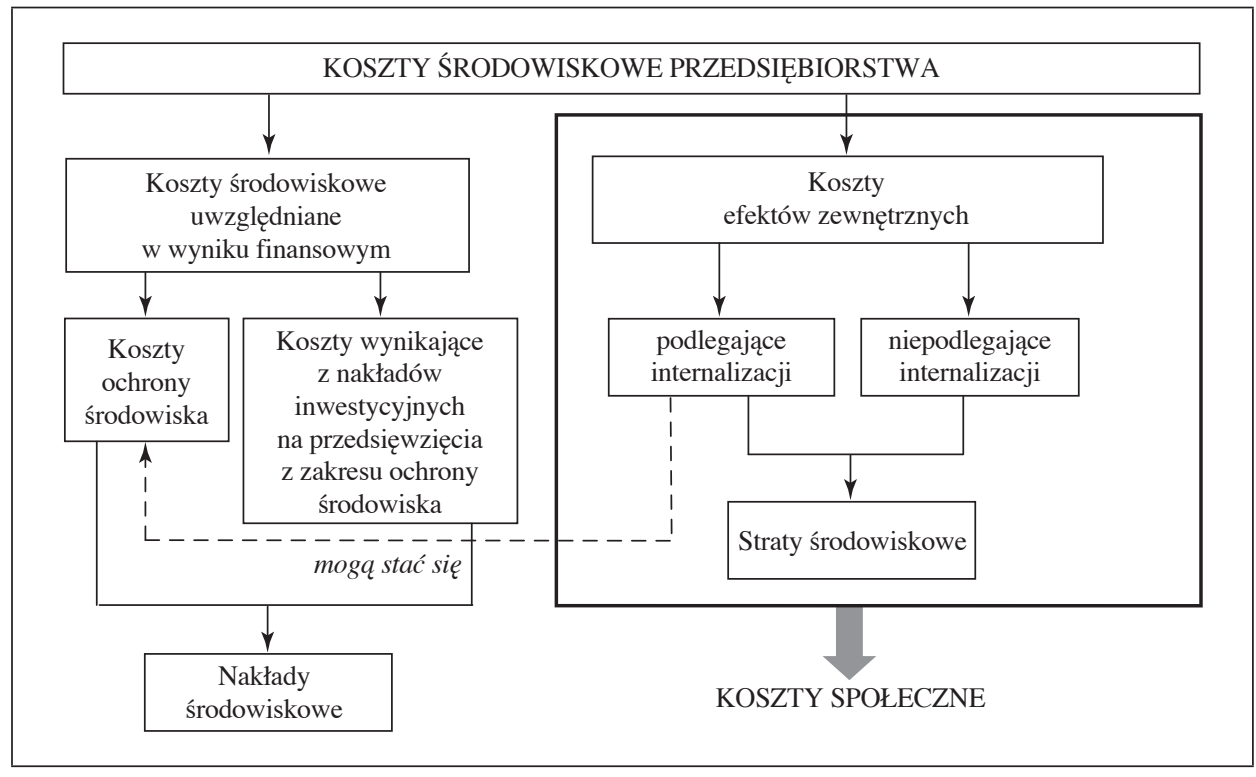

Rys. 1. Koszty środowiskowe przedsiębiorstwa

Źródło: opracowanie własne.

W literaturze anglojęzycznej z obszaru rachunkowości używa się różnych terminów na opisanie kosztów o charakterze społecznym i środowiskowym. Wśród nich wymienić należy: external costs (Jasinski, Meredith i Kirwan 2015, s. 1124; Antheaume 2004; Dascalu i in. 2010, s. 24), negative externalities (Fagerström, Kågström i Hartwig 2019, s. 159; Unerman, Bebbington i O’Dwyer 2018, s. 500), negative social externalities (Unerman, Bebbington i O'Dwyer 2018, s. 505), societal costs (Dascalu i in. 2010, s. 24). Koszty zewnętrzne (external costs) definiowane są jako szkody bądź negatywne efekty wynikające z działań bądź podejmowanych decyzji jednostki gospodarczej ponoszone przez jednostki z tym niezwiązane (Jasinski, Meredith i Kirwan 2015, s. 1124). C. Dascalu 
i in. (2010, s. 25) zaliczają do nich: degradację środowiska, w tym wyczerpanie zasobów naturalnych, hałas i skutki estetyczne, resztkowe emisje do powietrza i wody, długoterminowe usuwanie odpadów, za które firmy nie ponoszą odpowiedzialności prawnej, oraz niekorzystny wpływ na ludzi, ich własność i dobrobyt, nieskompensowane skutki zdrowotne, zmianę lokalnej jakości życia, którą nie zawsze można zrównoważyć za pomocą systemów prawnych. Wymienieni autorzy zwracają także uwagę na stosowanie do opisu tego samego zjawiska pojęcia societal costs (koszty społeczne). A. Fagerström, J. Kågström i F. Hartwig (2019, s. 159) stosują pojęcie negative externalities (negatywne efekty zewnętrzne), ale go nie definiują. Skupiają się na zdefiniowaniu pojęcia externalities, przez które rozumieją korzyści lub koszty ponoszone nie przez strony transakcji, a przez osoby trzecie. J. Unerman, J. Bebbington i B. O’Dwyer (2018, s. 500) uważają, że negatywne efekty zewnętrzne występują, gdy osoba fizyczna lub organizacja będąca stroną trzecią ponosi koszty wynikające $\mathrm{z}$ transakcji między innymi podmiotami i nie ma możliwości odzyskania tych kosztów od stron transakcji.

W literaturze anglojęzycznej od jakiegoś czasu prowadzone są badania i rozważania nad externalities, czyli zewnętrznym wpływem działalności podmiotów na jednostki trzecie, i ich miejscem $\mathrm{w}$ rachunkowości. W tabeli 1 zaprezentowano najważniejsze badania $\mathrm{z}$ tego zakresu.

Tabela 1. Badania z zakresu rachunkowości dotyczące efektów zewnętrznych w anglojęzycznej literaturze przedmiotu

\begin{tabular}{|c|c|c|c|}
\hline Autorzy & $\begin{array}{c}\text { Rok } \\
\text { publikacji }\end{array}$ & Tytuł & Czasopismo \\
\hline $\begin{array}{l}\text { A. Fagerström, } \\
\text { J. Kågström i F. Hartwig }\end{array}$ & 2019 & $\begin{array}{l}\text { Sustainability Accounting } \\
\text { for Externalities }\end{array}$ & $\begin{array}{l}\text { „Sustainability. } \\
\text { The Journal of Record” }\end{array}$ \\
\hline $\begin{array}{l}\text { J. Unerman, } \\
\text { J. Bebbington } \\
\text { i B. O’Dwyer }\end{array}$ & 2018 & $\begin{array}{l}\text { Corporate Reporting } \\
\text { and Accounting for } \\
\text { Externalities }\end{array}$ & $\begin{array}{l}\text { "Accounting and Business } \\
\text { Research" }\end{array}$ \\
\hline $\begin{array}{l}\text { D. Jasinski, J. Meredith } \\
\text { i K. Kirwan }\end{array}$ & 2015 & $\begin{array}{l}\text { A Comprehensive Review } \\
\text { of Full Cost Accounting } \\
\text { Methods and Their } \\
\text { Applicability to the Automotive } \\
\text { Industry }\end{array}$ & $\begin{array}{l}\text { „Journal of Cleaner } \\
\text { Production" }\end{array}$ \\
\hline C. Dascalu i in. & 2010 & $\begin{array}{l}\text { The Externalities in Social } \\
\text { Environmental Accounting }\end{array}$ & $\begin{array}{l}\text { „International Journal of } \\
\text { Accounting \& Information } \\
\text { Management" }\end{array}$ \\
\hline N. Antheaume & 2004 & $\begin{array}{l}\text { Valuing External Costs - } \\
\text { from Theory to Practice: } \\
\text { Implications for Full Cost } \\
\text { Environmental Accounting }\end{array}$ & $\begin{array}{l}\text { „European Accounting } \\
\text { Review” }\end{array}$ \\
\hline
\end{tabular}

Źródło: opracowanie własne. 
W polskich czasopismach z zakresu finansów i rachunkowości brak natomiast badań związanych z externalities czy negative externalities. Znaleźć można badania nawiązujące ogólnie do informacji niefinansowych, lecz nie ma badań poświęconych wyłącznie wpływowi działalności przedsiębiorstw na otoczenie: na środowisko i społeczeństwo.

\section{Propozycja zdefiniowania kosztu społecznego w rachunkowości}

Nauka rachunkowości rozwija się w różnych kierunkach. Wśród poruszanych problemów są takie, które opisywane są dużo chętniej niż inne. Od kilku lat zauważa się w rachunkowości większą popularność badań naukowych odnoszących się do zrównoważonego rozwoju. Wskazać można bardzo wiele publikacji dotyczących: sprawozdawczości niefinansowej, sprawozdawczości zintegrowanej, rachunkowości społecznej czy zrównoważonej rachunkowości. Następuje rozwój rachunkowości przez przyjmowanie nowych pojęć, definicji, metod i modeli. Nie oznacza to, że wcześniejsze koncepcje są już nieaktualne. Są po prostu niewystarczające do rozwiązania kolejnych problemów. W związku z trwającymi obecnie badaniami i dyskusjami nad funkcjonowaniem przedsiębiorstw w dobie zrównoważonego rozwoju słusznym działaniem wydaje się wyodrębnienie i przyjęcie kosztu społecznego w rachunkowości oraz włączenie go do informacji niefinansowych wymaganych przepisami prawa bilansowego. Argumentami przemawiającymi za koniecznością zdefiniowania kosztu społecznego w rachunkowości jest występowanie: nurtu rachunkowości odpowiedzialności społecznej, teorii legitymizacji w rachunkowości, koncepcji całkowitego rachunku kosztów oraz dyrektywy w sprawie ujawniania informacji niefinansowych. Przesłanki te skłaniają do przyjęcia pojęcia kosztu społecznego, które będzie stanowiło podstawę do prowadzenia zaawansowanych badań w tym obszarze. Zaprezentowane wyniki przeprowadzonych badań literaturowych nad kosztem społecznym sugerują, żeby w rachunkowości definiować go jako negatywny wpływ działalności przedsiębiorstw na otoczenie: społeczeństwo i środowisko, który wynika z występowania kosztów efektów zewnętrznych i przyczynia się do ponoszenia strat społecznych i środowiskowych. Wyodrębnienie i określenie kategorii kosztu społecznego w rachunkowości spowoduje, że konieczne będzie wypracowanie kolejnych rozwiązań w m.in. w zakresie:

- identyfikowania i rejestrowania działań mających negatywny wpływ na społeczeństwo i środowisko, które przyczyniają się do strat społecznych i środowiskowych,

- pomiaru i wyceny kosztów społecznych,

- sposobu i formy ujawniania kosztów społecznych, 
- formy i miejsca prezentacji kosztów społecznych w sprawozdawczości przedsiębiorstwa,

- narzędzi i procedur niezbędnych do przeprowadzenia audytu prezentowanych informacji na temat kosztów społecznych.

Dlatego warto zastanowić się nad aktualnością już istniejących definicji, pojęć i terminów. Można stwierdzić, że jednym z popularniejszych i najczęściej wykorzystywanych pojęć w rachunkowości jest koszt. Rozpatruje się go w dwojaki sposób - jako zużycie zasobów przedsiębiorstwa bądź utratę wartości posiadanych zasobów. Koszt przedsiębiorstwa rozumiany jako zużycie szczegółowo definiuje się jako zużycie zasobów posiadanych bądź nabytych. Innymi słowy, koszt dotyczy tylko tych zasobów, które stanowią własność przedsiębiorstwa oraz powstały w wyniku dokonanej transakcji. Należy wziąć jednak pod uwagę, że jednostki w trakcie swojej działalności wykorzystują nie tylko zasoby posiadane, ale także zasoby społeczne i środowiskowe. Wykorzystanie to przejawia się we wpływie prowadzonej działalności wywieranym na społeczeństwo i środowisko. Przejawia się on w uszczupleniu zasobów społecznych i środowiskowych, przedsiębiorstwo nie ponosi jednak z tego tytułu odpowiedzialności ani większych konsekwencji. Włączenie zużycia zasobów społecznych i środowiskowych do definicji kosztów w nauce rachunkowości niewątpliwie będzie miało zatem wpływ na realizację celu rachunkowości odpowiedzialności społecznej polegającego na uwzględnieniu obciążeń dla społeczeństwa wynikających z działalności konkretnego podmiotu gospodarczego. Powyższe rozważania skłaniają do tego, aby koszt w nauce rachunkowości rozumieć jako wyrażone wartościowo zużycie w danym okresie w związku z prowadzoną działalnością zasobów przedsiębiorstwa, a także zasobów społecznych i środowiskowych stanowiących dobro publiczne. Prezentowana definicja ma charakter wyłącznie postulatywny. Jej uwzględnienie przyczyni się do rozszerzenia zakresu badań w obszarze rachunkowości społecznej odpowiedzialności oraz uzupełni definicję kosztu przedsiębiorstwa.

\section{Wnioski}

Zmiany klimatyczne, niszczenie bioróżnorodności, generowanie hałasu, wykorzystywanie rzadkich zasobów naturalnych to tylko niektóre kwestie środowiskowe, za które odpowiedzialna jest działalność człowieka, w tym działalność przedsiębiorstw. Rachunkowość jako źródło informacji przestała spełniać w tym zakresie swoją funkcję. Obecnie stoją przed nią nowe zadania polegające na dostarczaniu informacji o wpływie działalności przedsiębiorstw na społeczeństwo i środowisko. Na konieczność tę wskazują: nurt rachunkowości społecznej odpowiedzialności, teoria legitymizacji, koncepcja całkowitego rachunku kosztów oraz dyrektywa 
w sprawie ujawniania informacji niefinansowych. W polskiej literaturze przedmiotu znaleźć można rozważania, w których widoczna jest świadomość występowania kosztów społecznych, brak natomiast bardziej szczegółowych badań poświęconych wyłącznie temu obszarowi. W literaturze anglojęzycznej toczy się dyskusja na ten temat, ale można stwierdzić, że są to dopiero początki badań w tym zakresie. Tymczasem temat jest ważny i interesujący, badania w tym obszarze wydają się zaś niezwykle potrzebne.

\section{Literatura}

Adamczyk J. (2019), The Quality of Non-financial Information in the Perspective of Data Disclosure, ,Prace Naukowe Uniwersytetu Ekonomicznego we Wrocławiu”, vol. 63, nr 10, https://doi.org/10.15611/pn.2019.10.11.

Aerts W., Cormier D. (2009), Media Legitimacy and Corporate Environmental Communication, ,Accounting, Organizations and Society”, vol. 34, nr 1, https://doi.org/10.1016/ j.aos.2008.02.005.

Aluchna M., Kytsyuk I., Roszkowska-Menkes M. (2018), Raportowanie społecznej odpowiedzialności biznesu. Przypadek spótek z WIG20, „Studia i Prace Kolegium Zarządzania i Finansów", nr 170.

Antczak J. (2014), Informacje o środowisku w systemie rachunkowości, „Prace Naukowe Uniwersytetu Ekonomicznego we Wrocławiu", nr 329, https://doi.org/10.15611/ pn.2014.329.01.

Antheaume N. (2004), Valuing External Costs - from Theory to Practice: Implications for Full Cost Environmental Accounting, ,European Accounting Review”, vol. 13, nr 3, https://doi.org/10.1080/0963818042000216802.

Archel P., Husillos J., Larrinaga C., Spence C. (2009), Social Disclosure, Legitimacy Theory and the Role of the State, „Accounting, Auditing \& Accountability Journal”, vol. 22, nr 8, https://doi.org/10.1108/09513570910999319.

Bebbington J., Gray R.H. (2001), An Account of Sustainability: Failure, Success and a Reconceptualization, „Critical Perspectives on Accounting”, vol. 12, $\mathrm{nr}$ 5, https://doi. org/10.1006/cpac.2000.0450.

Bebbington J., Russell S., Thomson I. (2017), Accounting and Sustainable Development: Reflections and Propositions, „Critical Perspectives on Accounting”, vol. 48, https:// doi.org/10.1016/j.cpa.2017.06.002.

Bek-Gaik B., Surowiec A. (2019), Raportowanie zintegrowane w praktyce polskich spótek - próba oceny jakości ujawnień, „Prace Naukowe Uniwersytetu Ekonomicznego we Wrocławiu", vol. 63, nr 11, https://doi.org/10.15611/pn.2019.11.14.

Bengtsson S., Sjöborg L. (2004), Environmental Costs and Environmental Impacts in a Chemical Industry, Doctoral Dissertation, M. Sc. Thesis, Chalmers University of Technology, Göteborg, Sweden.

Beuren I.M., Boff M.L. (2011), Predominant Strategies of Legitimacy in Environmental and Social Disclosures, ,Management Research: Journal of the Iberoamerican Academy of Management", vol. 9, nr 1, https://doi.org/10.1108/1536-541111146641. 
Biadacz R. (2016), Czynniki warunkujace rozwój rachunkowości w XXI wieku wybrane problemy, ,Finanse, Rynki Finansowe, Ubezpieczenia”, nr 2(80), https://doi. org/10.18276/frfu.2016.2.80/2-02.

Biadacz R. (2017), Rachunkowość społeczna w świetle badań polskich autorów, ,Zeszyty Teoretyczne Rachunkowości", nr 94(150), https://doi.org/10.5604/01.3001.0010.4993.

Chojnacka E., Jadanowska E. (2020), Użyteczność i korzyści ujawniania informacji niefinansowych - wyniki badania ankietowego przeprowadzonego wśród spółek notowanych na Giełdzie Papierów Wartościowych w Warszawie, ,Zeszyty Teoretyczne Rachunkowości", vol. 106, nr 162, https://doi.org/10.5604/01.3001.0013.8998.

D’Onza G., Greco G., Allergini M. (2016), Full Cost Accounting in the Analysis of Separated Waste Collection Efficiency: A Methodological Proposal, ,,Journal of Environmental Management", vol. 167, https://doi.org/10.1016/j.jenvman.2015.09.002.

Dascalu C., Caraiani Ch., Lungu C.I., Colceag F., Guse G.R. (2010), The Externalities in Social Environmental Accounting, ,International Journal of Accounting \& Information Management", vol. 18, nr 1, https://doi.org/10.1108/18347641011023252.

Dyląg R., Puchalska E. (2014), Raportowanie zagadnień środowiskowych i społecznych, ,Zeszyty Teoretyczne Rachunkowości”, nr 75(131), https://doi.org/10.5604/ 16414381.1098727.

Fagerström A., Kågström J., Hartwig F. (2019), Sustainability Accounting for Externalities, „Sustainability”, vol. 12, nr 3.

Famielec J., Brodniewicz E. (2006), Odzwierciedlenie aspektów ochrony środowiska $w$ sprawozdawczości małych i średnich przedsiębiorstw $w$ świetle ustawy o rachunkowości, Opracowanie na zlecenie Ministerstwa Gospodarki, Białystok-Kraków.

Fijałkowska J. (2013), Zakres ujawnień w raportach społecznej odpowiedzialności i zrównoważonego rozwoju przedsiębiorstw, ,Prace Naukowe Uniwersytetu Ekonomicznego we Wrocławiu", nr 311.

Gabrusewicz T. (2010), Rachunkowość odpowiedzialności społecznej w kształtowaniu zasad nadzoru korporacyjnego, Wydawnictwo C.H. Beck, Warszawa.

Gabrusewicz T. (2011), Rola systemu współczesnej rachunkowości w teorii zrównoważonego rozwoju, „Zeszyty Naukowe/Uniwersytet Ekonomiczny w Poznaniu”, nr 174.

Garstecki D. (2015), Czy rachunkowość społecznej odpowiedzialności zasługuje na miano paradygmatu?, „Prace Naukowe Uniwersytetu Ekonomicznego we Wrocławiu”, nr 388.

Georgiou O., Jack L., (2011), In Pursuit of Legitimacy: A History behind Fair Value Accounting, ,The British Accounting Review”, vol. 43, nr 4, https://doi.org/10.1016/ j.bar.2011.08.001.

Gray R., Bebbington J. (2001), Accounting for the Environment, Sage, London.

Gray R., Javad M., Power D.M., Sinclair C.D. (2001), Social and Environmental Disclosure and Corporate Characteristics: A Research Note and Extension, ,Journal of Business Finance \& Accounting”, vol. 28, nr 3-4, https://doi.org/10.1111/1468-5957.00376.

Higgins C., Stubbs W., Milne M. (2018), Is Sustainability Reporting Becoming Institutionalised? The Role of an Issues-based Field, ,Journal of Business Ethics”, vol. 147, nr 2, https://doi.org/10.1007/s10551-015-2931-7.

Jasch C. (2003), The Use of Environmental Management Accounting (EMA) for Identifying Environmental Costs, ,, Journal of Cleaner Production”, vol. 11, nr 6, https://doi. org/10.1016/S0959-6526(02)00107-5. 
Jasinski D., Meredith J., Kirwan K. (2015), A Comprehensive Review of Full Cost Accounting Methods and Their Applicability to the Automotive Industry, ,Journal of Cleaner Production", vol. 108, https://doi.org/10.1016/j.jclepro.2015.06.040.

Jastrzębowski A. (2014), Teoria legitymizacji a funkcje rachunkowości, „Studia Oeconomica Posnaniensia", vol. 2, nr 4(265).

Kassenberg A. (2011), Globalne problemy ekologiczne i ich konsekwencje dla rozwoju gospodarczego, ,Biuletyn PTE”, nr 2(52).

Kawacki M. (2018), Ujawnianie informacji niefinansowych w raportach rocznych spółek, Uniwersytet Ekonomiczny w Poznaniu, praca doktorska.

Kosiuk A. (2013), Rachunkowość odpowiedzialności społecznej spółek giełdowych indeksu RESPECT, „Prace Naukowe Uniwersytetu Ekonomicznego we Wrocławiu”, nr 311.

Krasodomska J. (2014a), Informacje niefinansowe w sprawozdawczości spółek, Wydawnictwo Uniwersytetu Ekonomicznego w Krakowie, Kraków.

Krasodomska J. (2014b), Rachunkowość społeczna - perspektywa światowa i krajowa, „Prace Naukowe Uniwersytetu Ekonomicznego we Wrocławiu”, nr 329, https://doi. org/10.15611/pn.2014.329.20.

Krasodomska J. (2018), Raportowanie zintegrowane a społeczna odpowiedzialność przedsiębiorstw, „Prace Naukowe Uniwersytetu Ekonomicznego we Wrocławiu”, nr 503.

Lament M. (2017), Raportowanie informacji niefinansowych $w$ zakładach ubezpieczeń w Polsce, ,Zeszyty Teoretyczne Rachunkowości”, nr 91, https://doi.org/ 10.5604/01.3001.0009.8024.

Liu J., Taylor D. (2008), Legitimacy and Corporate Governance Determinants of Executives' Remuneration Disclosures, Corporate Governance, ,The International Journal of Business in Society, vol. 8, nr 1, https://doi.org/10.1108/14720700810853400.

Łada M. (2016), Legitymizacja a społecznie odpowiedzialna rachunkowość, ,Zeszyty Naukowe Politechniki Częstochowskiej Zarządzanie”, nr 23, t. 2, https://doi.org/ 10.17512/znpcz.2016.3.2.01.

Łada M., Kozarkiewicz A. (2013), Teoria legitymizacji w badaniach z zakresu rachunkowości, ,Zeszyty Teoretyczne Rachunkowości”, nr 71(127), https://doi.org/ $10.5604 / 16414381.1061654$.

Macuda M. (2015), Rachunkowość odpowiedzialności społecznej-raportowanie zagadnień środowiskowych, ,Studia Oeconomica Posnaniensia”, vol. 3, nr 1.

Martyniuk T., Romanchuk K. (2019), Corporate Social Responsibility Reporting - Polish and Ukrainian Experience, ,Zeszyty Naukowe Małopolskiej Wyższej Szkoły Ekonomicznej w Tarnowie", nr 43(3).

Matuszak Ł. (2015), Raportowanie o społecznej odpowiedzialności przedsiębiorstw (CSR) za pomocq narzędzia legitymizacji przedsiębiorstw, ,Studia Oeconomica Posnaniensia", vol. 3, nr 1.

Mikulska T., Michalczuk G. (2014), Raportowanie społecznej odpowiedzialności przedsiębiorstwa, ,Zeszyty Naukowe Uniwersytetu Szczecińskiego nr 827. Finanse, Rynki Finansowe, Ubezpieczenia", nr 69.

Milne M.J., Gray R. (2007), Future Prospects for Corporate Sustainability Reporting Sustainability Accounting and Accountability 1. 
Nowak A. (2014), Problemy pomiaru społecznej odpowiedzialności biznesu, „Prace Naukowe Uniwersytetu Ekonomicznego we Wrocławiu”, nr 329, https://doi.org/ 10.15611/pn.2014.329.25.

Ogden S., Clarke J. (2005), Customer Disclosures, Impression Management and the Construction of Legitimacy, ,Accounting, Auditing \& Accountability Journal”, vol. 18, nr 3, https://doi.org/10.1108/09513570510600729.

Ogrodnik P. (2019), Standardy stosowane w raportowaniu niefinansowym przez polskie spółki z sektora odzież i obuwie, notowane na rynku podstawowym Giełdy Papierów Wartościowych w Warszawie, ,Studia i Prace Kolegium Zarządzania i Finansów”, nr 173.

Papaj-Wlisłocka E. (2020), Uwarunkowania ujawnień danych niefinansowych w sprawozdaniach z działalności spółek notowanych na Giełdzie Papierów Wartościowych $w$ Warszawie, Uniwersytet Ekonomiczny w Katowicach, praca doktorska.

Paszkiewicz A., Szadziewska A. (2011), Raportowanie rozwoju zrównoważonego przedsiębiorstw wedtug wytycznych GRI, ,Zeszyty Naukowe Uniwersytetu Szczecińskiego nr 668. Finanse, Rynki Finansowe, Ubezpieczenia”, nr 41.

Piontek B. (1999), Koszty środowiskowe w rachunku kosztów funkcjonowania kopalni węgla kamiennego, Rocznik Ochrona Środowiska, t. 1, Środkowo-Pomorskie Towarzystwo Naukowe Ochrony Środowiska, Koszalin.

Power M.K. (2003), Auditing and the Production of Legitimacy, ,Accounting, Organizations and Society", vol. 28, nr 4, https://doi.org/10.1016/s0361-3682(01)00047-2.

Remlein M. (2015), Doświadczenia polskich grup kapitałowych w zakresie zintegrowanej sprawozdawczości, ,Studia Oeconomica Posnaniensia”, vol. 3, nr 1.

Remlein M. (2019), Społecznie odpowiedzialne inwestycje w sprawozdawczości przedsiębiorstw, Wydawnictwo Uniwersytetu Ekonomicznego w Poznaniu, Poznań.

Rogall H. (2010), Ekonomia zrównoważonego rozwoju: teoria i praktyka, Zysk i S-ka, Poznań.

Rubik J. (2018), Raportowanie niefinansowe spółek RESPECT INDEX po zmianach, „Studia Ekonomiczne”, nr 369.

Sikacz H., Wołczek P. (2017), Analiza raportów informacji niefinansowych spółek z RESPECT Index, „Marketing i Rynek”, nr 11.

Skoczylas W. (2019), Społeczna odpowiedzialność biznesu w świetle analizy zawartości raportów niefinansowych spółek makrosektora produkcja przemysłowa i budowlano-montażowa, ,Zeszyty Teoretyczne Rachunkowości”, nr 103(159), https://doi. org/10.5604/01.3001.0013.3081.

Śnieżek E. (2016), Raportowanie społecznej odpowiedzialności biznesu. Studium przypadku Lasów Państwowych, Wydawnictwo Uniwersytetu Łódzkiego, Łódź.

Śnieżek E., Perlińska M. (2012), Rachunkowość i sprawozdawczość finansowa w dobie zrównoważonego rozwoju, ,Acta Universitatis Lodziensis. Folia Oeconomica”, nr 276.

Stanek-Kowalczyk A.N. (2019), Czynniki wpływajace na zakres danych ujawnianych przez przedsiębiorstwa $w$ raportach niefinansowych, Szkoła Główna Handlowa w Warszawie, praca doktorska.

Szadziewska A. (2012), Klasyfikacja i ujmowanie kosztów środowiskowych przedsiębiorstwa w sprawozdaniach zewnętrznych, „Zeszyty Teoretyczne Rachunkowości”, nr 65(121),

Szadziewska A. (2013), Rola rachunkowości w pomiarze efektywności działań CSR, „Zarządzanie i Finanse”, R. 11, nr 4, cz. 4. 
Szadziewska A. (2014a), Prezentowanie informacji na temat społecznej odpowiedzialności w sprawozdawczości zewnętrznej przedsiębiorstw, „Prace Naukowe Uniwersytetu Ekonomicznego we Wrocławiu", nr 329, https://doi.org/10.15611/pn.2014.329.28.

Szadziewska A. (2014b), Rachunkowość jako źródło informacji na temat realizacji strategii społecznej odpowiedzialności biznesu, „Zeszyty Teoretyczne Rachunkowości”, nr 75(131), https://doi.org/10.5604/16414381.1098779.

Unerman J., Bebbington J., O'Dwyer B. (2018), Corporate Reporting and Accounting for Externalities, „Accounting and Business Research”, vol. 48, nr 5, https://doi.org/10.1080/ 00014788.2018.1470155.

Zyznarska-Dworczak B. (2014), System rachunkowości zarzq̨dczej w dobie społecznej odpowiedzialności przedsiębiorstw, ,Studia Oeconomica Posnaniensia”, vol. 2, nr 5(266).

Zyznarska-Dworczak B. (2015). Wiarygodność raportowania zintegrowanego w świetle strategiczno-informacyjnego paradygmatu rachunkowości, ,Studia Oeconomica Posnaniensia", vol. 3, nr 1 .

Zyznarska-Dworczak B. (2018), Legitimacy Theory in Management Accounting Research, „Problemy Zarzadzania”, vol. 16, nr 1(72), https://doi.org/10.7172/1644-9584.72.12.

\section{Social Costs in Accounting}

(Abstract)

Objective: To present the role of accounting from the point of view of the development of accounting in sustainable development and to propose a definition of externalities in accounting.

Research Design \& Methods: An analysis of the subject literature was conducted and coupled with logical deduction.

Findings: The role of accounting in sustainable development is in providing information about the influence a company's activities have on the environment and society. This role arises from the existence of several factors, including social responsibility in accounting, the theory of legitimacy in accounting, the concept of full cost accounting, and the directive on the disclosure of non-financial information.

Implications / Recommendations: It is important today to begin tracking external costs more precisely in accounting, to treat them as a new area of research and to carry on the research and studies connected with measuring and evaluating social costs and include them in the company's financial performance.

Contribution: Observing externalities in accounting and including them could help strengthen the scope of research areas in accounting for sustainable reporting and complete the definition of cost in accounting, which is behind the curve due to the growing trend of sustainable development.

Keywords: externalities in accounting, non-financial reporting, corporate responsibility accounting, directive on non-financial information, non-financial information, external costs. 